University of Pennsylvania Carey Law School

Penn Law: Legal Scholarship Repository

Faculty Scholarship at Penn Law

1998

\title{
Migration as International Trade: The Economic Gains from the Liberalized Movement of Labor
}

Howard F. Chang

University of Pennsylvania Carey Law School

Follow this and additional works at: https://scholarship.law.upenn.edu/faculty_scholarship

Part of the Immigration Law Commons, International Business Commons, International Trade Law Commons, Labor and Employment Law Commons, Labor Economics Commons, Law and Economics Commons, Law and Society Commons, Social Welfare Commons, Social Welfare Law Commons, Taxation Commons, Taxation-Transnational Commons, and the Work, Economy and Organizations Commons

\section{Repository Citation}

Chang, Howard F., "Migration as International Trade: The Economic Gains from the Liberalized Movement of Labor" (1998). Faculty Scholarship at Penn Law. 1210.

https://scholarship.law.upenn.edu/faculty_scholarship/1210

This Article is brought to you for free and open access by Penn Law: Legal Scholarship Repository. It has been accepted for inclusion in Faculty Scholarship at Penn Law by an authorized administrator of Penn Law: Legal Scholarship Repository. For more information, please contact PennlawIR@law.upenn.edu. 


\title{
MIGRATION AS INTERNATIONAL TRADE: THE ECONOMIC GAINS FROM THE LIBERALIZED MOVEMENT OF LABOR
}

\author{
Howard F. Chang ${ }^{*}$
}

\section{INTRODUCTION}

Since multilateral trade negotiations produced the General Agreement on Tariffs and Trade (GATT) ${ }^{1}$ in Geneva in 1947, the world has made dramatic progress toward free trade in goods. Several subsequent rounds of negotiations under the GATT have steadily liberalized international trade, and numerous regional initiatives seek to deepen economic integration among countries prepared to go further. Standard economic theory prescribes free trade as the regime that maximizes global economic welfare. Economists also

\section{Copyright 1998 by Howard F. Chang}

- Prof essor of Law, University of Southern California Law School; Visiting Professor of Law, Stanford Law School. Parts of this article have appeared previously in Howard F. Chang, Liberalized Immigration as Free Trade: Economic Welfare and the Optimal Immigration Policy, 145 U. PA. L. REV. 1147 (1997). I wish to thank participants at the UCLA symposium and at workshops at Stanford Law School, the University of Michigan Law School, and the Duke University School of Law for usef ul comments.

1 General Agreement on Tariffs and Trade, Oct. 30. 1947, 61 Stat. pt. 5, 55 U.N.T.S. 187 [hereinafter GATT]. 
recommend trade liberalization as a policy that is likely to produce gains for each country.

The gains from trade arise from the fact that different countries will produce various goods at different costs. When countries restrict trade, the price of a good will be low in countries that can produce the good at low cost, but its price will be high in countries that can produce the good only at higher cost. Liberalized trade allows both countries to gain: the high-price country can import the good at a price less than it what it would cost to produce the good at home; the lowprice country can export the good and receive a higher price than it would otherwise fetch.

Precisely the same theory applied to trade in goods also applies to trade in services. The Uruguay Round of trade negotiations recognized this fact in 1994, extending the international regulation of trade to service markets through the General Agreement on Trade in Services (GATS). ${ }^{2}$ Free trade in all services, including labor services, would imply free movement of people across borders. To provide many services, workers must cross borders to where the work must be performed, either on a temporary basis or to accept permanent employment. Thus, the free movement of workers across borders promotes economic welfare by promoting free trade in the labor market. The European Union recognizes the importance of free mobility of labor as an element of a comprehensive free trade regime, enshrining this freedom in its constitution as one of the "four freedoms" that are the basic pillars of the European common market, "an area without internal frontiers in which the free movement of goods, persons, services, and capital is ensured." This "freedom of movement for workers" in turn entails "the abolition of any

2 General Agreement on Trade in Services, Apr. 15, 1994. 33 I.L.M. 1167 [hereinafter GATS]. For a summary of the GATS, see Michael J. TRebilcock \& Robert Howse. The Regulation of International Trade 225-36 (1995), Bernard Hoekman, The General tgreement on Trade in Services, in LEGal Problems of INTERnational ECONOMiC Relations: Cases. Materials AND Text 921 (John H. Jackson et al., eds., 3d ed. 1995), or Pierre Sauve, Assessing the General Agreement on Trade in Services--Half-Full or HalfEmpty?. J. World Trade. Aug. 1995. at 125.

3 Treaty Establishing the European Economic Community Mar. 25, 1957, 298 U.N.T.S. 11, art. 8A (as amended in 1987), art. 7A (as amended in 1992). 
discrimination based on nationality between workers ... with respect to employment."

Immigration barriers interfere with the free flow of labor internationally and thereby cause wage rates for the same class of labor to diverge widely among different countries. For any given class of labor, residents of high-wage countries could gain by employing more immigrant labor, and residents of low-wage countries could gain by selling more of their labor to employers in high-wage countries. Economic efficiency in the global labor market would call for unrestricted migration, which would allow labor to move freely to the country where it earns the highest return. Market forces would thus direct labor to the market where its marginal product is highest. Given the large international differences in wages, it should be apparent that the potential gains from international trade in labor (and the costs we bear as a result of immigration barriers) are large.

Indeed, studies suggest that the gains to the world economy from removing immigration barriers could well be enormous and greatly exceed the gains from removing trade barriers. For example, Bob Hamilton and John Whalley provide estimates that suggest that the gains from free migration of labor would more than double worldwide real income, indicating that immigration controls "are one of the (and perhaps the) most important policy issues facing the global economy." Even their most conservative estimate suggests that the gains would be a significant fraction (over thirteen percent) of worldwide real income. ${ }^{6}$ Furthermore, their analysis indicates that the free migration of labor would also greatly improve the global distribution of income by raising real wages dramatically for the world's poorest workers.'

Recognizing the importance of immigration barriers as costly trade barriers, developing countries, especially India, have pressed for liberalized movement of labor as part of the liberalization of world trade in services. India, with the support of the Philippines, Egypt,

\footnotetext{
+ Id. at art. 48(2).

5 Bob Hamilton \& John Whalley, Efficiency and Distributional Implications of Global Restrictions on Labour Mobility. 14 J. DEV. ECON. 61. 70 (1984).

6 See id. at $71-72$.

7 See id. at 73-74
} 
Brazil, and Pakistan, has threatened to block progress on the liberalization of trade in financial services in the absence of progress on the "movement of natural persons," which is the subject of a parallel set of negotiations in the World Trade Organization (WTO). ${ }^{8}$ In spite of the large efficiency gains that liberalized immigration policies would produce, however, the authors of the GATS were careful to avoid imposing any obligations with respect to immigration policies. $^{9}$

Indeed, in 1995 the U.S. Commission on Immigration Reform, headed by Barbara Jordan, urged Congress to move radically in the opposite direction, toward more restrictive immigration laws. ${ }^{10}$ The Jordan Commission recommended sweeping changes in longstanding U.S. immigration laws, including a reduction in the overall level of legal immigration into the United States by one-third." The proposed changes included permanent cuts in both employment-based and family-based immigration.' ${ }^{2}$ These proposals would entail the most restrictive changes in U.S. immigration law since immigration quotas were first introduced in 1921. ${ }^{13}$ President Bill Clinton immediately

8 See India Warns of Financial Services Link to Free Flow of Labor in Negotiations, 12 Int'l Trade Rep. (BNA) 649 (Apr. 12, 1995): Financial Services Committee Approves Accord Without U.S. 12 Int'l Trade Rep. (BNA) 1311, 1311 (Aug. 2, 1995).

9 See GATS, supra note 2. Annex on Movement of Natural Persons Supplying Services Under the Agreement, para. 2. 33 1.L.M. 1187. 1187 [hereinafter GATS Annex] ("The Agreement shall not apply to measures affecting natural persons seeking access to the employment market of a Member, nor shall it apply to measures regarding citizenship, residence or employment on a permanent basis.").

10 See U.S. Comm'n on Immigration Reform. Legal immigration: Setting Priorities (1995) [hereinafter JORDAN COMM'N].

"See id, at xii; Robert Pear, Change of Policy on U.S. Immigrants Is Urged by Panel, N.Y. Times, June 5, 1995, at Al.

12 The Jordan Commission proposed permanent reductions in the numerical limits for employment-based admissions (from 140,000 to 100,000 per year) and for family-based admissions (from 480,000 to 400,000 per year). See JORDAN COMM'N. supra note 10, at xii. The Commission also proposed the complete elimination of all family-based immigration categories other than nuclear family admissions. See id. at xviii.

13 Immigration quotas are a relatively recent innovation: the United States did not introduce quantitative restrictions on immigration until 1921. See Act of May 19, 1921, ch. 8, $\$ 2($ a), 42 Stat. 5, 5. Thus, for most of our history, the United States admitted immigrants without numerical limits. 
endorsed these proposals. ${ }^{14}$ Senator Alan Simpson and Representative Lamar Smith, both Republicans, soon introduced bills to implement the Jordan Commission's recommendations. ${ }^{15}$ These radical cuts in legal immigration proved controversial, however, and after heated debate, both the House of Representatives and the Senate ultimately voted to exclude these cuts from their immigration reform bills. ${ }^{16}$ Nevertheless, the Commission reiterated its restrictionist recommendations in its 1997 report to Congress, ${ }^{17}$ and observers expect restrictionists in Congress to revive their efforts to implement these proposals in the near future. ${ }^{18}$

The Commission asserted that its proposals would serve "the national interest," citing a recent report that it had commissioned from the National Research Council, ${ }^{19}$ which presents the most thorough analysis of the economic effects of immigration conducted so far. Yet as Commissioner Warren Leiden observed in his statement dissenting from the Jordan Commission's proposal to reduce legal immigration, the Commission "can provide no convincing argument for this drastic reduction" because "there is no objective basis for a drastic reduction." 20 In fact, as this article will show, the application of trade principles to immigration law, together with the results of the Council's empirical analysis, suggests instead that specific liberalizing reforms, which are likely to increase levels of employment-based and family-based immigration by eliminating certain immigration barriers,

14 See Robert Pear. Clinton Embraces a Proposal to Cut Immigration by a Third, N.Y. TIMES. June 8,1995 , at B 10 .

is See H.R. 2202, 104th Cong. (1995) (the Smith bill); S. 1394, 104th Cong. (1995) (the Simpson bill).

16 See House Approves Immigration Bill After Removing Legal Immigration Restrictions, 73 INTERPRETER RELEASES 349 (Mar. 25, 1996); Senate Approves Omnibus Immigration Bill After Removing Exclusion Provisions, 73 INTERPRETER RelEASES 601 (May 6. 1996).

17 See U.S. COMm'n On IMmigration Reform, BeCOMing an AMERICAN: IMmigration AND IMmigRANT POLICY, at $x$ vii, 59 (1997) [hereinafter CIR].

is See William Branigin, Immigration Issues Await New Congress: Surging Legal Influx Will Be Among Topics of Renewed Debate. WASH. POST, Nov. 18, 1996, at A1.

19 See CIR. supra note 17, at 59 (citing National Research Council, The New americans: Economic, Demographic, and Fiscal Effects of Immigration (James P. Smith \& Barry Edmonston eds., 1997) [hereinafter NRC]).

20 JORDAN COMM'N, supra note 10, at 229. 
would raise national economic welfare as well as global economic welfare.

Given the importance of economic concerns in the public debate over immigration policy, I will focus on the implications of immigration for economic welfare. Although the economic theory that I use applies to any country of immigration, I will focus on the United States as my central example, taking the empirical evidence regarding immigration into the United States and deriving policy implications for the United States in particular. In particular, this article will begin with a focus on immigration for the purpose of employment, because it is largely justified on economic grounds, although the analysis will have implications for immigration in general. I will use the term "immigration" in a broad sense, including not only the admission of aliens for permanent residence (on "immigrant" visas) but also the admission of guest-workers on a more temporary basis (on what are called "nonimmigrant" visas in the United States). ${ }^{21}$ Thus, I will focus on the issue of admission to the labor market of the host country, which does not necessarily imply access to citizenship in the host country.

Before reaching any conclusions regarding the optimal level of immigration, one must specify the criterion by which one will evaluate the effects of immigration. To shed light on our immigration laws, I will explore what policies would be optimal from the perspective of economic welfare. In evaluating the effects of immigration policies upon economic welfare, however, we must first address the question of whose welfare we are considering. Should we seek to maximize the welfare of natives (those born in the country of immigration) alone? Should we seek to maximize national economic welfare or global economic welfare? Once we decide whose welfare counts, we must also address whether our objective is merely to maximize their wealth (that is, to pursue economic efficiency with respect to their welfare) or our objectives also include an equitable distribution of wealth among them. If our objectives include distributive concerns, then our

21 U.S. law creates numerous categories of "nonimmigrant" aliens admitted to the United States on a temporary basis. 8 U.S.C. \$ $1101(a)(15)(1994)$. These categories include not only students, see id. $\$ 1101(\mathrm{a})(15)(\mathrm{F})$, and temporary visitors for business or pleasure, see id. $\$ 1101(\mathrm{a})(15)(\mathrm{B})$, for example, but also temporary workers, see id. $\$ 1101(\mathrm{a})(15)(\mathrm{H})$. 
measure of social welfare must specify how much weight to give these concerns. Thus, the optimal policy will depend upon what measure of social welfare we choose to maximize.

I will not in this article set forth a philosophical defense of any particular welfare objective. Instead, my strategy will be to examine what policies the United States would pursue if its goal were simply to maximize the economic welfare of U.S. natives, not because I believe that immigration policy should be guided solely by considerations of economic self-interest, but because such concerns have in fact played a dominant role in the public debate over immigration policy. National governments, including the U.S. government, will probably continue to deem the promotion of the interests of natives as the paramount objective of immigration policies. I derive the optimal policy given that objective as a theoretical exercise, not because this welfare objective is morally defensible, but because this objective is commonly thought to provide a strong case in favor of restrictive immigration laws.

This thought experiment reveals, however, that even from this narrow perspective, which "stacks the deck" against the immigrant, optimal policies would probably allow higher levels of employmentbased and family-based immigration than current U.S. immigration laws permit. Even if we give zero weight to the welfare of aliens in our measure of social welfare, the optimal immigration policy would be more liberal than our current laws in most important respects. In particular, although the economic welfare of natives and distributive justice among natives are often advanced as reasons to reduce immigration, I will demonstrate that neither objective provides a sound justification for more restrictive laws regarding employmentbased and family-based immigration.

In Part II, I examine immigration policies that efficiently promote the welfare of natives, setting aside questions of distribution. I conclude that optimal policies would probably entail higher levels of employment-based and family-based immigration than we currently allow into the United States. For example, the U.S. should eliminate both the quantitative restrictions and the "labor certification" requirements currently imposed on employment-based immigration. 
Optimal immigration policy would instead take the form of a "tariff," that is, a tax imposed on immigrants. This tariff could take the form of an income tax that discriminates between citizens and aliens. Although some economists have previously suggested a tax on foreign workers, ${ }^{22}$ my comprehensive analysis builds on that suggestion by exploring the features of the optimal immigration tariff in detail. I find that the optimal tariff is positive for immigrants with low incomes but is likely to be negative for immigrants with sufficiently high incomes. These results suggest that skilled immigration should be permitted (indeed encouraged) without quantitative or other protectionist restrictions and that unskilled immigration should be permitted without quantitative restrictions but subject to less generous fiscal policies than those applied to natives.

In Part III, I introduce distributive justice among natives as an objective. Concern for the distribution of income among natives, however, does not imply that more restrictive immigration laws are in order. Instead, the appropriate response to distributive concerns is redistribution through progressive reforms of tax and transfer policies, not immigration restrictions. Finally, in Part IV, I explore the normative implications of my economic analysis and formulate proposals for liberalizing U.S. immigration laws in light of some of the political realities that inhibit such reforms.

\section{National ECONOMIC WELFARE}

I begin my analysis of the optimal immigration policy from the standpoint of national economic welfare defined narrowly, in terms of the wealth of natives alone. First, I will consider the effects of

22 See, e.g.. Jagdish N. Bhagwati \& T.N. Srinivasan, On the Choice Berween Capital and Labour Mobility, 14 J. INT'L ECON. 209, 218-19 (1983); Barry R. Chiswick. The Impact of Immigration on the Level and Distribution of Economic Well-Being, in THE GATEWAY: $\backslash$ U.S. IMMigration Issues and Policies 289, 308-09 (Barry R. Chiswick ed., 1982); Melvyn B. Krauss \& William J. Baumol, Guest Workers and Income-Transfer Programs Financed by Host Governments, 32 KYKLOS 36, 44 (1979); Alan O. Sykes, The Welfare Economics of Immigration Law: A Theoretical Survey with an Analysis of U.S. Policy, in JUSTICE IN IMMIGRATION 158, 180-82 (Warren F. Schwartz ed., 1995). 
immigration upon natives through labor markets, setting aside economic effects that operate outside the market. Second, I will extend the analysis to include the effects of immigration upon natives through the public sector.

\section{A. Effects of Immigration Through the Labor Market}

For a country with no market power in international markets, such that it cannot affect world prices, standard trade theory prescribes free trade to maximize national economic welfare. Import quotas or tariffs restrict trade and thereby sacrifice gains from trade. Protectionism imposes costs by driving up the price paid by domestic consumers for the goods in question. As a result consumption falls, leading to deadweight loss insofar as consumers forego consumption even if the value they would derive from it exceeds the amount paid to foreigners for the imported good. Domestic production also rises, leading to deadweight loss insofar as productive resources are drawn from alternative uses more valuable than the amount paid to foreigners for the imported good. Domestic producers may gain from higher prices for their goods, but this gain comes only at the expense of consumers, who must pay these higher prices. The gain to domestic producers is a pure transfer from consumers. Indeed, because protectionism causes distortions in domestic production and consumption, consumers lose more than domestic producers gain. The national economy as a whole suffers a net loss as a result of protectionism.

The same theory indicates that free immigration would maximize the gains from trade in the labor market for a country with no market power in foreign labor markets. Immigration restrictions impose costs by driving up the cost of labor, which in turn drives up the cost of goods and services to consumers. Native workers may gain from higher wages, but this gain comes only at the expense of employers in the host country and ultimately consumers. The increase in wages for domestic labor is a pure transfer from owners of other factors of production (for example, capital and land) in the host country and from consumers. Immigration restrictions not only redistribute wealth among natives but also destroy wealth by causing economic distortions. Restrictions prevent employers from hiring foreign 
workers even if the value that they would produce exceeds the wage that would be paid to the worker. Immigration restrictions entail a sacrifice of this "immigration surplus." ${ }^{23}$ Thus, the U.S. private sector would benefit from the elimination of all restrictions on the immigration of labor.

If a country nevertheless chooses to protect a domestic market, standard trade theory recommends tariffs over quotas. Both tariffs and quotas sacrifice gains from trade, but tariffs produce some revenue for the govermment, which quotas do not. Quotas make the right to import scarce and therefore valuable. This value derives from prices in the importing country that are higher than those available on the world market. The scarcity of quota rights create "quota rents," which an importing country could capture by selling the right to import. In practice, countries do not sell these rights, allowing importers to enjoy these quota rents. A tariff that restricts trade to a level equivalent to a quota will capture these quota rents in the form of tariff revenue.

Similarly, if a country restricts immigration of labor, the optimal restriction would take the form of a tariff, not quotas. Quotas allow immigrants to keep the quota rents in the form of after-tax wages higher than those that prevail in alternative labor markets. A tariff could take the form of a charge for admission, which would be similar to quantitative restrictions with an auction to allocate the available visas to those potential immigrants. By selling visas, the country of immigration can capture the quota rents that would otherwise go to the immigrant. A tariff, however, could also take the form of a discriminatory income tax, rather than a payment up front, which would have the advantage that the immigrant would not need to have

23 George J. Borjas. The Economic Benefits from Immigration. J. ECON. PERSP.. Spring 1995, at 3, 5 [hereinafter Borjas, Economic Benefits from Immigration]. Borjas estimates that immigration into the United States has produced a surplus of $\$ 7$ billion per year. See id. at 7. The National Research Council surveys similar estimates, "on the order of $\$ 1$ to $\$ 10$ billion a year," which "may be modest relative to the size of the U.S. economy, but ... remains a significant positive gain in absolute terms." NRC, supra note 19, at 153 . Higher levels of immigration would bring a more than proportionate increase in the immigration surplus because the marginal benefits of immigration increase with the quantity of immigration: more of the decline in domestic wages comes at the expense of immigrant workers rather than natives. Therefore, we would expect a more liberal policy to produce much larger total economic benefits for natives. 
the resources to pay the tariff at the border. ${ }^{24}$ The immigrant could pay the tariff as extra income taxes withheld from income earned after immigration. ${ }^{25}$

For a country with some market power, protectionist trade policies will have an effect on prices on the world market. In this case, standard trade theory predicts that the country can improve on free trade by imposing the "optimal tariff." 26 The optimal tariff would still entail costly distortions, but it would also bring a gain to the importing country by driving down the price received by foreigners for the imported goods. The importing country can thus extract more of the gains from trade through tariff revenues.

The same principles apply to imported labor. To the extent the U.S. can affect wages abroad, it has market power in the market for foreign labor, and it can gain by imposing a "tariff" on immigrant labor (that is, a discriminatory tax imposed only upon foreign workers). Under these conditions, the burden of a tariff would fall not only on employers and consumers but also on immigrant labor, because the tariff would drive the after-tax wages of migrants below

24 See Chiswick. supra note 22, at 309 (proposing that the U.S. allow immigrants "to substitute an annual surcharge on their federal income tax as an alternative to [a] large entry fee"); Julian L. Simon, Auction the Right to Be an Immigrant, N.Y. TimES, Jan. 28, 1986, at A25 (suggesting that the United States “allow 'buyers' to enter now and pay later together with income tax").

25 Some commentators have suggested that efforts to impose discriminatory taxes on immigrants could encounter constitutional objections. See, e.g., Bhagwati \& Srinivasan. supra note 22. at 211 ("[T]he (discriminatory) taxation by the country of residence of foreign labour is fraught with numerous difficulties from legal, constitutional, human-rights and political standpoints."); Chiswick, supra note 22, at 309 n.34 (predicting that an "annual income tax surcharge" would raise the objection "that it is unconstitutional"). The U.S. Supreme Court. however, has applied a lenient standard of review to federal laws that discriminate against aliens. See John E. Nowak \& Ronald D. Rotunda. Constitutional LAw \$14.12, at 704 (4th ed. 1991) (noting that "it would appear that the federal government may use a citizenship classification so long as it is arguably related to a federal interest " and that "alienage classifications created by federal law will be subjected to only the rational basis standard of review“). In .Mathews v. Diaz, 426 U.S. 67 (1976), the Court held that Congress could provide federal medical insurance to citizens while restricting the access of aliens to this program. This deferential standard of review for federal laws discriminating against aliens in the distribution of welfare benefits suggests that the Court would uphold similar restrictions on alien access to tax benefits, such as the earned income tax credit. See infra note 39.

26 See Richard E. Caves \& Ronald W. Jones, World Trade and Payments: An INTRODUCTION 212-13 (4th ed. 1985). 
what they would be in a world of free trade in labor. To maximize national economic welfare, a country with some market power in the relevant market would raise taxes on migrants so as to shift income from immigrant workers to the public treasury. For a sufficiently small tariff, the gains from raising tax revenues at the expense of migrant workers would exceed the costs of deterring valuable immigration. The government would capture these gains for the benefit of natives in the form of tariff revenue. The optimal tariff would vary depending on the type of labor, because different classes of labor would entail different market conditions. Thus, a discriminatory income tax would have an advantage over a uniform charge for admission, insofar as it could impose a tariff that is a function of income.

\section{B. External Effects of Immigration}

The foregoing analysis considered the economic effects of immigrant labor through the labor market alone. Immigrants, however, also have economic effects that are not internalized by private participants in that market. An immigration tariff, for example, yields benefits for the public sector, not for the private sector. Indeed, much of the debate over the economic effects of immigration has focused on the effects on the public sector. ${ }^{27}$ The presence of the public sector introduces external effects that must be included in the analysis.

These effects include both benefits and costs, so that depending on the immigrant, it is possible for the net external effect to be positive or negative. First, like natives, immigrants pay taxes, including income taxes, social security taxes, sales taxes, and property taxes. All these taxes introduce an additional reason to value immigrants: they increase tax revenues by expanding the tax base. Second, an immigrant also imposes external costs. For example, to the extent that an immigrant receives transfer payments from the government or has access to other public entitlement programs, these transfers will represent a cost to the

See, e.g., NRC, supra note 19, at 254-362. 
country of immigration. Immigrants also gain access to public goods when they immigrate. To the extent they are pure public goods, like national defense, immigrants can enjoy the public good without imposing any cost on natives. Immigrant access to other public goods, however, may aggravate problems of congestion. Roads, for example, may become congested more frequently or more severely.

Some immigrants may impose external costs in excess of the taxes they pay. Those immigrants who pay the least in such taxes would be the most likely to impose net external costs on natives. Thus, the net effect of an immigrant on the public sector may be positive or negative, so that the marginal benefit to a private employer of hiring a foreign worker may understate or overstate the marginal benefit to the "importing" country from the immigration of that worker.

Thus, because skilled workers tend to have higher incomes and to pay more in taxes, it is especially in the national economic interest to promote their immigration. The National Research Council, for example, found that the average immigrant with more than a highschool education pays enough in taxes to produce a net fiscal benefit. ${ }^{28}$ As long as they make a positive contribution to the public sector, there is in general no economic justification for excluding these immigrants. Quantitative or other protectionist restrictions on their immigration should be eliminated.

To the extent that unskilled workers tend to have lower incomes, they tend to pay less in taxes and to take greater advantage of public entitlement programs, so that the benefits flowing to the national economy from their immigration may be reduced and may be negative. The Council found that the average immigrant with less than a high-school education imposes a net fiscal cost. ${ }^{29} \mathrm{~A}$ net negative effect through the public sector introduces a possible justification for restricting their immigration. The international trade perspective, however, suggests that if some immigrants have a negative effect on the public sector, the optimal response is not non-tariff restrictions on immigration, such as quotas. Rather, the appropriate response is fiscal. In such cases, we can use a tariff, that is, a tax imposed only on

2s See id at 334 (Table 7.5).

29 See id. 
immigrants, to restrict access to all our public goods and public entitlements.

\section{The Optimal Tariff on Unskilled Immigrants}

Suppose unskilled immigrants would have a negative effect on the public sector in the absence of a tariff, and consider the optimal tariff for natives to levy on them. A tariff would increase the contribution of these immigrants to the public coffers as well as discourage their immigration. We could, for example, impose a tariff high enough to ensure the marginal immigrant's net effect on the public sector is zero. This "Pigouvian" tariff can reduce immigration to a level that equates the marginal benefits to natives with the marginal costs imposed on natives by immigration, including congestion costs. ${ }^{30}$ Because the tariff would ensure that the marginal immigrant would impose no net external cost, this tariff would eliminate any immigration expected to have a negative effect on national economic welfare. The resulting Pigouvian level of immigration would be first-best from the perspective of maximizing the welfare of natives.

Although this level of immigration would be efficient in this sense, it will nevertheless be in the interest of natives to raise the tariff still higher. A tariff above Pigouvian levels will reduce immigration below optimal levels, but will in general produce gains sufficient to justify this distortion. Governments need revenues to finance the provision of public goods, but most taxes they use to raise revenues will cause costly distortions in the economy. These distortions imply an "excess burden" of taxation: taxes impose costs on the private sector that exceed the revenue collected by the government. ${ }^{31}$ An optimal tax system will seek to minimize the excess burden associated with raising

30 A "Pigouvian" tax causes each person to internalize the negative externality imposed on others. Richard Cornes \& Todd Sandler. The Theory of Externalities, Public Goods, and Club Goods 52 (1986); see David A. Starrett, Foundations of Public Economics 51 (1988). The term "Pigouvian" refers to the economist A.C. Pigou, who suggested such corrective taxes as a solution to the problem of negative externalities. See A.C. PIGOU. THE ECONOMICS OF WELFARE 192 (4th ed. 1932).

31 See David N. Hyman, Public Finance: A Contemporary Application of Theory to POLICY 384 (4th ed. 1993 ). 
any given amount of tax revenue. Because tariff revenue raised from immigrants would allow distortionary taxes elsewhere in the economy to be reduced, optimal-tax considerations would call for a tariff even if it causes some distortion in the level of immigration. An optimal tariff would be higher than that which induces the optimal quantity of immigration. Thus, the optimal tariff would assure that each immigrant makes on balance a net positive contribution to the public sector.

Thus, for immigrants who would otherwise have a negative economic effect on the public sector, the optimal tariff is unambiguously positive. The larger the (nondiscriminatory) taxes paid by an immigrant, however, the more valuable the immigrant will be for public coffers, and the less inclined we should be to levy a positive tariff in addition to these other taxes. Indeed, for skilled immigrants who would on balance have a sufficiently positive economic effect on the public sector, the optimal tariff could well be zero or even negative.

\section{The Optimal Tariff on Skilled Immigrants}

Consider skilled immigrants who have a net positive effect on the public sector even in the absence of a tariff. To analyze how the external net benefits associated with these immigrants affect the calculation of the optimal tariff, suppose first that the country of immigration has no market power: the supply of immigrants is perfectly elastic. In this case, there is no "market power" basis for a positive optimal tariff, because the incidence of taxes falls only upon employers, who must pay higher wages as a result of taxes, not upon the immigrants.

Given these assumptions, it is likely to be in the national economic interest to discriminate in favor of skilled immigrants in our income tax rates. The fact that these immigrants make net positive contributions to the public sector implies that their tax payments are above Pigouvian levels and thus high enough to distort their immigration below first-best levels and produce deadweight loss. Lower taxes would expand immigration toward the first-best level, which would bring a gain for the economy as a whole. 
A complete analysis, however, would also consider the need to raise tax revenues. Taking these effects into account still points toward lower tax rates on immigrant labor if the supply of this labor is perfectly elastic. Optimal-tax theory prescribes lower tax rates on markets where supply or demand is more elastic, so as to minimize the excess burden of taxation. ${ }^{32}$ Thus, suppose that skilled immigrants pay enough in taxes other than income taxes (such as sales taxes and property taxes) to cover any external costs they impose on natives. Optimal-tax theory would prescribe higher income taxes on natives than on immigrants as long as the supply of their labor is less elastic than the perfectly elastic supply of immigrant labor. Lower taxes on immigrants would increase immigration, which would generate new tax revenues as well as reduce the cost of labor for employers. Under these circumstances, the optimal tariff is unambiguously negative.

Suppose instead, however, that the supply of immigrant labor is less than perfectly elastic. If the supply of immigrant labor is upwardsloping, then the optimal tariff is no longer unambiguously negative. Inelasticity of immigrant labor supply introduces two considerations that would cut in favor of higher tariffs.

First, "market power" considerations militate in favor of a positive tariff on immigrants. These considerations would tend to be weak, however, when nondiscriminatory taxes are already high. To the extent we have market power, income and wage taxes not only discourage immigration but also drive the after-tax wages of immigrants downward. Both these effects undercut the case for a positive tariff. The more immigrants pay in these other taxes, the greater the marginal costs of a tariff (we lose more tax revenues when immigration falls) and the smaller the marginal benefits (there are fewer immigrants whose after-tax wages will fall).

Second, the more inelastic the supply of immigrant labor, the less optimal-tax considerations militate in favor of negative tariffs. These considerations would still militate in favor of lower taxes on immigrants than on natives, however, as long as the supply of immigrant labor is more elastic than the supply of domestic labor. We

32 See id. at 386-87; Anthony B. Atkinson \& Joseph E. Stiglitz, Lectures on Public ECONOMICS 368-69 (1980). 
would expect this condition to hold over the relevant range of wages: the supply of domestic labor is elastic largely because native workers have the option of leaving the labor force, whereas immigrants have not only the option of leaving the labor force but also the option of remaining in their native countries and accepting employment there. Natives of a country of immigration are less likely than immigrants to respond to taxes by leaving (or failing to enter) the domestic labor market, because each worker is inclined, ceteris paribus, to remain in the worker's native country. Immigrants by definition have selfselected as workers willing to move, given the international differences in wage levels, but the costs of moving, both psychic and financial, imply that many would also decide not to move if taxes reduce the rewards to migration. Thus, the decision of each individual immigrant to supply labor to the country of immigration is likely to be more sensitive to taxes than the decision of natives to supply labor to the domestic labor market.

Furthermore, we would expect the elasticity of the supply of immigrant labor to be particularly large if the supply of immigrant labor is drawn from a world labor market that is large relative to the domestic labor market. Given the size of the world labor market, we would in general expect the supply of immigrant labor to be quite elastic. Thus, optimal-tax considerations not only militate in favor of a negative tariff, but these considerations may also be significant. Furthermore, the elasticity of immigrant labor supply also suggests that "market power" considerations in favor of positive tariffs may be weak.

Thus, the optimal tariff may be positive, but without precise information on elasticities and other data, the optimal tariff may also be negative. It is especially likely to be negative for classes of immigrants who already bear a high tax burden, because they are attractive from a fiscal perspective. For skilled immigrants expected to pay a large amount in income and other taxes, it is likely to be in the national interest to offer lower tax rates than those imposed on natives, in order to encourage the immigration of more taxpayers. 


\section{E. Immigration of Nuclear Families and Future Effects}

For simplicity of analysis the foregoing discussion has treated immigrants as simply individual workers. In reality, workers may often be reluctant to migrate without bringing close family members with them. What would be the optimal immigration policy regarding the admission of an immigrant worker's family? As long as the psychic and economic benefits of family unification (measured by the immigrants' willingness to pay for these benefits) exceed the congestion costs the additional immigrants would impose on natives, it will be optimal to allow workers to bring their relatives. These benefits are likely to be sufficiently large for a worker's immediate family (spouses and dependent minor children), who derive large benefits from cohabitation. Given the large benefits of keeping nuclear families united, the total benefits to the immigrant family would probably exceed any net external costs that these relatives would impose on natives, even after accounting for congestion costs.

With appropriate fiscal policies, natives can gain from the admission of these relatives. First, the immigrant household will pay more in sales and other taxes. Second, if these extra taxes are insufficient to create a net positive external effect of these additional immigrants, the immigrant family would be willing pay a higher tariff to compensate natives for any increase in external costs, such as congestion costs and any net transfers. By charging a higher tariff on larger immigrant families, natives can capture some of the surplus produced by family unification. The optimal tariff on an immigrant household would depend on the economic effects of the household as a whole and thus would be a function of the household's total income and size as well as the number of dependent minor children.

The effect of an additional family member on this optimal tariff raises an empirical question regarding the economic effect of that additional immigrant. In calculating this effect, we must take into account the effects that each immigrant will have over the entire life cycle, including the effects that each immigrant's descendants will have. The children and other descendants of the immigrant workers we admit will produce the same type of gains from trade in the labor market that the immigrants themselves will bring. These positive 
effects upon the private sector offer no reason to adjust the optimal tariff upward. The only possible negative effect would come through the public sector. Is there any reason to think that immigration will produce negative external costs?

To derive the optimal immigration policy, we would add up all future costs and benefits associated with each immigrant worker, including all the fiscal costs and benefits associated with that immigrant's descendants, discounting each cost and benefit to a net present value. With respect to each class of immigrant, we would estimate the expected total net present value on a per capita basis, which would be an average calculated in the face of uncertainty. We would count this expected value as one component of an immigrant's external effects. The only implication for the optimal immigration policy, then, would be an adjustment in the optimal tariff.

There is no reason to presume that these effects would call for a higher tariff. If these future effects produce a positive value for immigration, then a lower tariff would be optimal. Given the correlation between an immigrant's income and the income of the immigrant's descendants, we might expect skilled immigration to have a positive net effect through future generations. ${ }^{33}$ Furthermore, one would expect the descendants of even unskilled immigrants to assimilate and to obtain language and other skills that enable them to fare better than their parents in terms of economic performance. The available empirical evidence suggests that the children of immigrants do tend to outperform their parents on average..$^{34}$

In fact, the National Research Council has found that the descendants of current immigrants into the United States, whether these immigrants are highly educated or not, are likely to have a net positive fiscal effect overall: although the descendants of more educated immigrants tend to have larger positive effects, even the descendants of immigrants with less than a high-school education will

33 See George J. Borjas, The Economics of Immigration, 32 J. ECON. LIT. 1667, 1711-12 (1994) [hereinafter Borjas. Economics of Immigration] (discussing evidence that immigrant skill differentials persist over generations).

${ }^{34}$ See id. at 1711. 
on average have a significant positive effect. ${ }^{35}$ The Council estimates that once we take the positive fiscal effect of the immigrant's descendants into account, the average immigrant with less than a highschool education, for example, imposes only a modest net fiscal cost of $\$ 13,000$ in net present value in 1996 dollars. ${ }^{36}$ The corresponding fiscal impacts of more educated immigrants are positive: the average immigrant with a high-school education produces a net surplus of $\$ 51,000$, and the average immigrant with more than a high-school education produces a net surplus of $\$ 198,000 .{ }^{37}$ Furthermore, the Council's analysis also reveals that immigrants who arrive at age 21 or younger, whether highly educated or not, have a positive net fiscal effect. $^{38}$ This finding suggests that if an immigrant worker brings a dependent child as an immigrant into the United States, this child would represent a reason to reduce taxes on the immigrant worker, even from the perspective of the welfare of natives alone. Indeed, the Council's findings suggest that if an immigrant bears children after immigration, this fact would increase the economic benefits associated with that immigrant household and would represent a reason to adjust taxes on the household downward rather than upward.

\section{F. Restrictions on Public Benefits as a Positive Tariff}

A country of immigration may implement a positive tariff on immigration not only through a tax on immigrants but also through restrictions on immigrant access to public entitlement programs. Either form of tariff could improve the effect of immigration on the economic welfare of natives. Natives may gain, for example, by denying immigrants access to transfers, such as the earned income tax

35 See NRC. supra note 19. at 328 (Figure 7.10, Panel C). This result emerges because the descendants of relatively uneducated immigrants show substantial upward educational mobility. See id. at 356-57. The positive fiscal impact of an immigrant's descendants range from $\$ 76,000$ for an immigrant with less than a high-school education to $\$ 93,000$ for an immigrant with more than a high-school education. See id. at 334 (Table 7.5) (reporting net present value of average fiscal impacts in 1996 dollars).

36 See id. at 334 (Table 7.5).

37 See id.

38 See id. at 328 (Figure 7.10, Panel A). 
credit in the United States, which provides cash payments to lowincome workers. ${ }^{39}$ A positive tariff on immigrant labor can take the form of an income tax credit provided to all citizens but denied to aliens, combined with an otherwise nondiscriminatory income tax system.

The objective of reducing the burden immigrants impose on natives through the public sector underlies restrictions on the access of aliens to various entitlement programs. Under U.S. law, for example, even before Congress enacted new restrictions in 1996, ${ }^{40}$ aliens were generally ineligible for most public entitlements, including Medicaid, Aid to Families with Dependent Children (AFDC), and food stamps, unless they had been lawfully admitted for permanent residence. ${ }^{41}$ Thus, not only unauthorized immigrants but also aliens admitted to the United States temporarily as nonimmigrants, including temporary workers, were ineligible for most public benefits because they were not lawfully admitted for permanent residence. ${ }^{42}$ Current law now generally excludes nonimmigrants and unauthorized immigrants from an even broader range of public benefits: with only narrow exceptions, these aliens are ineligible for "any Federal public benefit."

39 For an examination of the eamed income tax credit, see Daniel Shaviro, The Minimum Wage, the Earned Income Tax Credit, and Optimal Subsidy Policy, 64 U. CHI. L. REv. 405 (1997): Anne L. Alstott. The Earned Income Tax Credit and the Limitations of Tax-Based Welfare Reform, 108 HARV. L. REV. 533 (1995).

to See Personal Responsibility and Work Opportunity Reconciliation Act of 1996, Pub. L. No. 104-193. 110 Stat. 2105.

4) See 42 U.S.C. \$ 1396b(v) (1994) (limiting the eligibility of aliens for Medicaid benefits); id. $\$ 602(\mathrm{a})(33)$ (limiting the eligibility of aliens for AFDC benefits); id. $\$ 1436$ a (limiting the eligibility of aliens for public housing assistance); 7 U.S.C. $\$ 2015$ (f) (1994) (limiting the eligibility of aliens for food stamps).

42 Aliens other than permanent residents, however, may be eligible for the earned income tax credit if they are resident aliens for tax purposes. See 26 U.S.C. \$32(c)(1)(E) (1994) (excluding nonresident aliens from the earned income tax credit). A lawful permanent resident is a resident alien for these purposes, but other aliens may also be resident aliens if they meet certain conditions. See id. $\$ 770 \mathrm{l}(\mathrm{b})(\mathrm{I})(\mathrm{A})$. For example, if an alien's presence in the United States satisfies the "substantial presence" test set forth in the statute, see id. $\$$ 7701 (b)(3), then the alien is treated as a resident.

438 U.S.C. $\$ 1611$ (a) (Supp. II 1996). Furthermore, the new law also prohibits states from providing "any State or local public benefit" to unauthorized immigrants unless the state subsequently enacts a law that "affirmatively provides for such eligibility." Id. \$ 1621 (Supp. Il 1996). The new law also makes explicit the exclusion of aliens from the earned income tax 
Current law also includes extensive new restrictions on the access of other aliens, including even legal permanent residents, to federal entitlement programs. In particular, an alien admitted for permanent residence after enactment of the new law is ineligible for "any Federal means-tested public benefit for a period of 5 years beginning on the date of the alien's entry into the United States," with only narrow exceptions. ${ }^{\text {t4 }}$ Furthermore, these permanent resident aliens are now ineligible for food stamps and for Supplemental Security Income (SSI) without regard to length of residence in the United States, with only narrow exceptions. ${ }^{45}$ Finally, the new law also permits states to exclude permanent resident aliens, including current recipients already admitted to the United States, from benefits under other federal programs, including Medicaid and Temporary Assistance for Needy Families (TANF), and under state programs, without regard to length of residence in the United States. ${ }^{46}$ The National Research Council estimates that by excluding immigrants from means-tested benefits for their first five years in the United States, this welfare legislation improves the total fiscal impact of the average immigrant by $\$ 8,000$ in net present value in 1996 dollars. ${ }^{47}$ This figure represents an estimate of the average value of the positive tariff imposed by the 1996 welfare legislation.

\section{G. Unemployment}

Unemployment poses two types of problems for immigration policy. The first arises from the unemployment of immigrants. The second arises from the unemployment of natives.

credit if they are not authorized to work in the United States. See 26 U.S.C. $\$ 32$ (Supp. 11 1996). Thus, unauthorized immigrants are ineligible for the earned income tax credit.

448 U.S.C. \$1613(a) (Supp. 11 1996).

45 Id. $\$ 1612(\mathrm{a})$. One exception applies to legal permanent residents who have "worked for 40 qualifying quarters." Id $\$ 1612(\mathrm{a})(2)(\mathrm{B})$. Thus, under this law, a permanent resident alien must work for a sufficient period of time to earn an entitlement to these benefits.

${ }^{46}$ See id. $\$ 1612$ (b) (allowing states to restrict alien access to designated federal programs); id. $\$ 1622$ (allowing states to restrict alien access to state public benefits). Each provision features exceptions that include legal permanent residents who have "worked for 40 qualifying quarters." Id. $\$ \$ 1612(\mathrm{~b})(2)(\mathrm{B}), 1622(\mathrm{~b})(2)$

${ }^{47}$ See NRC, supra note 19, at 339. 
First, indigent immigrants who are (or likely to become) unemployed may be unlikely to pay enough taxes to cover the costs of public entitlements that they would receive and the congestions costs that they would generate. For this reason, it may be prudent for the United States generally to reserve most employment-based immigration visas for those who have offers of employment in the United States (and their families). In fact, the immigration laws of the United States currently requires employer sponsorship for most categories of employment-based immigration visas. ${ }^{48}$ Furthermore, if immigrants who are unlikely to "pay their way" can be identified, and they do not have sponsors (such as relatives in the country of immigration) willing and able to support them, they can be excluded on that ground. The U.S. immigration statute authorizes the exclusion of aliens deemed "likely at any time to become a public charge."

Second, unemployment among native workers introduces another negative externality from immigration if immigrants increase the involuntary unemployment of natives. The U.S. immigration statute responds to this concern by imposing various restrictions, including quantitative restrictions and "labor certification" requirements, on the admission of employment-based immigrants and temporary workers. ${ }^{50}$

48 See 8 U.S.C. \$ 1154(a)(1)(D) (1994). The only exceptions are aliens with "extraordinary ability in the sciences, arts. education, business. or athletics." id. $1153(\mathrm{~b})(1)(\mathrm{A})$. "qualified special immigrants," $i d$. $\$ 1153(\mathrm{~b})(4)$, and "qualified immigrants secking to enter the United States for the purpose of engaging in a new commercial enterprise" that will employ U.S. workers, $i d$. $\$ 1153(\mathrm{~b})(5)(\mathrm{A})$. The relatively small number of immigrants falling into these categories, including especially skilled or wealthy aliens. may file petitions on their own behalf. See id $\$ 1154(\mathrm{a})(1)(\mathrm{C}),(\mathrm{E}),(\mathrm{F})$. Aliens seeking visas as temporary workers under U.S. law also require sponsoring employers. See id $\$$ $1101(\mathrm{a})(15)(\mathrm{H})$

498 U.S.C. \$1182(a)(4) (Supp. II 1996) ("Any alien who ... at the time of application for admission ... is likely at any time to become a public charge is inadmissible.").

so Employment-based immigration is normally capped at 140.000 visas, 8 U.S.C. $\$ 1151$ (d) (1994), but the qualitative restrictions are so stringent and the "labor certification" requirement so burdensome that this ceiling has not in fact been binding. In the 1996 fiscal year. for example, the United States admitted only 117.346 employment-based immigrants. See CIR, supra note 17, at 3. Furthermore, no more than 65.000 temporary workers may enter on $\mathrm{H}-\mathrm{l} \mathrm{B}$ visas "to perform services ... in a specialty occupation ... or as a fashion model," 8 U.S.C. $\$ 1101(\mathrm{a})(15)(\mathrm{H})(\mathrm{i})(\mathrm{b})(1994)$, and no more than 66,000 temporary workers may enter on $\mathrm{H}-2 \mathrm{~B}$ visas, $i d$. $\$ 101(\mathrm{a})(15)(\mathrm{H})(\mathrm{ii})(\mathrm{b})$. See $i d$. $\$ 184(\mathrm{~g})(1)$. Congress imposed these numerical limits on temporary workers only recently, in 1990, and these ceilings represent the 
Labor certification is a determination by the Department of Labor that "there are not sufficient workers who are able, willing, qualified, ... and available ... at the place where the alien is to perform" the work in question and that the employment of the alien "will not adversely affect the wages and working conditions of workers in the United States similarly employed." ${ }^{\text {I } 1}$ The U.S. immigration statute requires labor certification for most employment-based immigrants, even aliens "who are members of the professions holding advanced degrees or aliens of exceptional ability," professionals "who hold baccalaureate degrees," and others "performing skilled labor." ${ }^{\text {" }} 2$ Through the laborcertification requirement, the U.S. government requires U.S. employers to discriminate against foreign workers: the statute requires an employer to prefer any qualified U.S. worker over any foreign worker, no matter how much better qualified the foreign worker may be. ${ }^{33}$

As long as fiscal policies, employer sponsorship, and the "public charge" provision ensure that these immigrants and temporary workers are expected to have a net positive economic effect on natives, however, it would be in the economic interests of U.S. natives to admit them without protectionist "labor certification" requirements or quantitative restrictions. Indeed, immigration need not increase unemployment among natives at all. Immigrants not only expand the local supply of labor but also expand the local demand for labor. Immigrant workers will demand goods and services, and many of these goods and services will require locally supplied labor. In fact,

first quantitative restrictions ever imposed on any category of nonimmigrants. See STEPHEN H. LegOMSKy, Immigration and Refugee LaW and Policy 242 (2d ed. 1997).

518 U.S.C. $\$ 1182(\mathrm{a})(5)(\mathrm{A})(1994)$.

52 Id. \$1153(b)(2)-(3); see id. \$1154(b), 1182(a)(5)(D). The requirement also applies to temporary agricultural workers on $\mathrm{H}-2 \mathrm{~A}$ visas, see id. $\$ 1188(\mathrm{a})(\mathrm{I})$. and other temporary workers on H-2B visas, see 8 C.F.R. \$214.2(h)(6)(iv) (1998).

53 See LEGOMSKY, supra note 50, at 185 (“[T]he employer ordinarily must hire a minimally qualified American over a more qualified alien (or hire no one at all)."). The statute requires the U.S. worker to be "equally qualified" only in the case of an alien who "is a member of the teaching profession" or "has exceptional ability in the sciences or the arts." 8 U.S.C. $\$$ $1182(\mathrm{a})(5)(\mathrm{A})(1994)$. 
studies consistently demonstrate that immigration has little effect on the employment of natives. ${ }^{54}$

\section{H. Citizenship, Guestworkers, and Illegal Immigration}

Up to this point, I have analyzed immigration independent of the issue of naturalization as a U.S. citizen. The possibility of naturalization raises the question of whether discrimination against the immigrant would cease once the immigrant obtains citizenship. If so, then immigrants might anticipate citizenship and subsequent access to public entitlements. If the period of alienage is too short to permit the collection of the Pigouvian tariff, then fiscal policies limited to aliens may fail to deter all immigration with negative economic impact on natives.

We can, however, separate admission to the United States from access to naturalization. Indeed, under U.S. law, only aliens "admitted for permanent residence" may naturalize as U.S. citizens. ${ }^{55}$ Aliens admitted on nonimmigrant visas only, including temporary workers, are not admitted as permanent residents and are thus not eligible for most public entitlements and not eligible to naturalize. ${ }^{56}$

Classes of foreign workers deemed likely to have a negative economic impact if treated as citizens can be admitted on nonimmigrant visas without the same entitlement to citizenship implied by immigrant visas. The host country can keep an alien worker in guestworker status for as long as it deems necessary to collect the appropriate tariff. The collection of this tariff need not entail permanent status as an alien: the host country could allow the

5t Surveys of this empirical literature reveal wide consensus on this conclusion. See, e.g., Borjas, Economics of Immigration, supra note 33, at 1698 ("It is evident that immigration has a weak effect on the employment of natives."); Rachel M. Friedberg \& Jennifer Hunt, The Impact of Immigrants on Host Country Wages, Employment and Growth, J. ECON. PERSP., Spring 1995, at 23, 42 ("There is no evidence of economically significant reductions in native employment.").

558 U.S.C. \$1 1427(a) (1994).

56 See supra note 43. 
alien to naturalize after a sufficient probationary period has passed. ${ }^{57}$ The appropriate tariff would at least cover the present discounted value of any net costs that we expect the worker to impose on natives after the worker obtains U.S. citizenship.

The alternative to a guestworker program, for many migrant workers and for the United States, is probably entry as an unauthorized immigrant. A liberalized guestworker program would relieve the pressures in the labor market that generate unauthorized immigration. In fact, the United States brought in hundreds of thousands of agricultural guestworkers from Mexico annually for most years of the "bracero" program from 1942 to 1964, and the decline in admissions of such workers was closely correlated with the rise in the estimated number of unauthorized immigrants. ${ }^{58}$

Legalization of this migration would serve the interests of all parties concerned. The workers would gain from having a legal alternative to illegal entry and life as an unauthorized immigrant, which leaves them vulnerable to deportation by the govermment and to abuse by employers. Illegal immigration implies that the unauthorized immigrant must bear the costs of evading detection, apprehension, and deportation by the government. As a result, producers of counterfeit documents, smugglers, and unscrupulous employers can extract significant quota rents from the immigrant. Through a positive tariff, the government can collect some share of the value that immigrants would enjoy as a result of legal status, including quota rents they would otherwise transfer to forgers, smugglers, and unscrupulous employers. Natives would derive more benefit with these rents going

\$7 Nor would a guestworker program produce a hereditary class of alien residents in the United States, because the Fourteenth Amendment of the U.S. Constitution confers U.S. citizenship on anyone born in the United States, including the children of nonimmigrants. See U.S. CONST. amend. XIV, \$ 1 ("All persons born or naturalized in the United States, and subject to the jurisdiction thereof, are citizens of the United States and of the State wherein they reside."); United States v. Wong Kim Ark, 169 U.S. 649. 676 (1898). Thus, guestworker programs in the United States cannot create the type of caste society that they might in countries that do not provide birthright citizenship.

58 See Julian L. Simon, The Economic Consequences of ImMilgration 302 (1989) ("Experience with the bracero program provides solid evidence that a legal temporary worker program will indeed reduce illegal immigration ...."); see also id. at 286 (Figure 15.1). 
to the public treasury instead, which would allow a reduction in other taxes.

More skilled immigrants, however, will make positive contributions to the public sector even when treated as citizens. There would be little reason from an economic perspective to deny these immigrants access to citizenship or to delay their naturalization for a significant period of time. On the contrary, because their presence yields external benefits, it is in the interest of the country of immigration to promote their immigration and to strengthen their ties to the host country. Legal status that includes the option of U.S. citizenship in relatively short order would make our offer more attractive to prospective skilled immigrants and increase the likelihood that they will stay once they take up residence here. Thus, at least in the case of skilled immigrants, we can offer quick access to U.S. citizenship and simultaneously further the economic interest of natives.

In fact, the categories of employment-based immigration visas under U.S. law are largely designed to select particularly skilled or wealthy immigrants for permanent residence. ${ }^{59}$ Quotas for employment-based immigration allocate most visas to "priority workers," which include aliens with "extraordinary ability," "outstanding professors and researchers," and "multinational executives and managers," to "members of the professions holding advanced degrees or aliens of exceptional ability," and to other "skilled workers" and "professionals." 60 The vast majority of employment-based immigrants enter through these categories. ${ }^{61}$ Few unskilled workers can obtain such visas: of the 140,000 visas allocated

59 As a result, the National Research Council finds that "[n]ew immigrants admitted under employment-preference visas have substantially greater earnings than those in other categories." NRC, supra note 19, at 194.

${ }^{60} 8$ U.S.C. \$ $1153(\mathrm{~b})(1)-(3)$ (1994).

${ }^{61}$ See JORDAN COMM'N, supra note 10, at 89 (Chart 25). Smaller numbers of visas are available for unskilled workers, see 8 U.S.C. \$1153(b)(3)(A)(iii), (B) (1994), for "qualified special immigrants," id. \$1153(b)(4), and for foreign investors, who must invest at least $\$ 1$ million in a new commercial enterprise that will create at least ten jobs in the United States, see id. $\$ 1153(\mathrm{~b})(5)$. 
to employment-based immigration per year, only 10,000 may go to unskilled workers. ${ }^{62}$

More employment-based visas are available for unskilled workers who enter as nonimmigrants. Unskilled workers may enter on H-2A visas as agricultural workers, which are not subject to a quantitative restriction, or on $\mathrm{H}-2 \mathrm{~B}$ visas for workers who come "temporarily to the United States to perform ... temporary service or labor," which are limited to 66,000 per year. ${ }^{63}$ This "double requirement of "temporariness"" requires the $\mathrm{H}-2 \mathrm{~B}$ alien not only to enter temporarily but also to fill a temporary job. ${ }^{64}$ Furthermore, both visas are subject to labor certification requirements. ${ }^{65}$ As a result of these requirements, the demand for each of these visas have remained low, but the liberalization or elimination of these requirements could greatly increase use of these programs. ${ }^{66}$

Employment-based immigration of unskilled workers into the United States has largely taken the form of illegal rather than legal immigration, with this unauthorized immigrant population currently growing by as many as 300,000 aliens each year. ${ }^{67}$ Given that unauthorized immigrants have little access to public entitlements for as long as their presence remains unauthorized, they may make a positive contribution to public coffers under the fiscal policies currently applied to them. Without distinguishing between legal and illegal immigrants, the National Research Council found that once we take the positive fiscal effect of the immigrant's descendants into account, an immigrant with less than a high-school education imposes

\footnotetext{
2 See 8 U.S.C. \$\$ 1151(d)(1)(A), 1153(b)(3)(A)(iii), (B) (1994).

${ }^{63}$ Id. \$1101(a)(15)(H)(ii); see id. \$1184(g)(1)(B).

64 Thomas A. Aleinikoff et al., immigration and Citizenship: Process and Policy 395 (4th ed. 1998).

65 See 8 U.S.C. $\$ 1188(\mathrm{a})(1)$ (1994); 8 C.F.R. \$214.2(h)(6)(iv) (1998).

66 Admissions under $\mathrm{H}-2 \mathrm{~B}$ visas has remained below one third of the quota limit in recent years, and admissions under H-2A visas have been similar. AlEINIKOFF ET AL.. supra note 64, at 393, 395; see id. at 395 ("It is clear, however, that the demand would be much higher but for the double 'temporariness' requirement."); Sykes, supra note 22, at 189 (reporting that "[a]dmissions under the $\mathrm{H}-2$ categories have been modest in recent years, on the order of 35,000 for the two combined" and explaining that "because of the transaction costs of obtaining a visa coupled with the limited certifications for labor shortages in the agricultural sector. employers often find that these visas are not worth the effort to procure").

67 See NRC, supra note 19, at 51.
} 
a net fiscal cost of only $\$ 13,000$ in net present value in 1996 dollars, ${ }^{68}$ and that if the 1996 welfare legislation excludes immigrants from seven specified means-tested benefits for only their first five years in the United States, then the total fiscal impact of the average immigrant would improve by $\$ 8,000 .{ }^{69}$ The Council's figures suggest that if an immigrant never has access to such benefits, as would be the case for an unauthorized immigrant who never obtains legal status, then such an immigrant would probably have a positive fiscal impact even if the immigrant is unskilled.

These figures also suggest that at current levels of immigration, the tariff that would be sufficient to internalize the net fiscal costs of an unskilled guestworker would be well below the prohibitive level. ${ }^{70}$ The degree of international inequality in wages, the magnitude of unauthorized immigration into the United States, and the fees that unauthorized immigrants are willing to pay to smugglers suggest that a large number of aliens would be willing to enter as guestworkers even if this required paying a significant fraction of their income as a

${ }^{68}$ See id. at 334 (Table 7.5).

69 See id. at 339 (assuming that these programs include "SSI, AFDC, food stamps, nonemergency Medicaid. energy assistance, rent subsidies. and public housing").

70 If the Council's figures represent the fiscal impact of the average unskilled guestworker. such a tariff may come to only several thousand dollars. which even a minimum-wage worker could plausibly pay within a period of several years. A truly temporary worker, however. would remain in the United States only while employed and would then return home, imposing even less of a burden on the public treasury than a permanent resident. See Sykes. supra note 22. at 189 ("Temporary workers are even less likely than permanent immigrants to be a net drain on the public sector, given that these workers pay taxes just like anyone else, federal funds cannot be used to provide them with public safety net benefits, and their right to remain in the country generally depends on continuing employment.") (footnote omitted). Immigrants are likely to make a positive contribution to the public treasury during their working years and impose a burden only if they remain in the United States for their retirement years and gain access to public benefits. See NRC, supra note 19, at 315 (Figure 7.9). Thus, to avoid a negative fiscal impact, we would only need to collect a tariff from a guestworker who remained in the United States as a permanent resident. For example, we could collect a tariff from all guestworkers and offer a rebate for any guestworker who chooses to return home, retaining only the tariff revenue necessary to cover the cost of any public benefits provided to the guestworker. For guestworkers who wish to remain in the United States permanently, we could offer the option of adjusting their status to permanent residence once they had paid a sufficient tariff. The Council's estimates suggest that a modest tariff may be sufficient to cover the expected net fiscal costs of the permanent residence of an average unskilled immigrant. 
tariff. $^{71}$ More unskilled workers would probably enter under a liberalized guestworker policy without quotas than under our current laws, even if we were to impose the optimal tariff on these guestworkers and continue to exclude them from most public benefits.

Under current employment-based immigration policies, the United States reserves permanent residence, and thus citizenship, for the skilled and the wealthy. Those admitted as immigrants to the United States are eligible to apply for citizenship after a five-year waiting period. ${ }^{72}$ Given that the optimal tariff may well call for discrimination in favor of skilled immigrants and against similarly skilled natives, we might view an offer of citizenship after a short waiting period as an efficient supplement or alternative to a negative tariff. That is, the option value of citizenship for the skilled immigrant, whether psychic or economic, would probably equal or exceed any economic cost to natives from making this offer. Therefore, an offer of U.S. citizenship for skilled immigrants after a short waiting period would be an efficient means for improving our offer of employment in the United States.

\section{Family-Based Immigration as a Negative Tariff}

Similarly, immigration laws that allow skilled immigrants to petition for the immigration of their relatives might be viewed as an efficient substitute for an explicit negative tariff. That is, the right to sponsor relatives for immigration visas on more favorable terms than

1 Unauthorized immigrants from Mexico, for example, have recently reported that they receive wages in the United States nearly nine times what they receive in Mexico. See Mexican Deportees Report Good Treatment, UPI. Apr. 21. 1996. available in LEXIS. Nexis Library. UPI File (reporting that Mexican immigrants received an average of $\$ 278$ per week in the United States, compared with $\$ 30.81$ per week in Mexico). Given such large disparities in wages, unauthorized immigrants are willing to pay large sums to smugglers for entry into the United States. See Somini Sengupta, Crackdowns Have Smugglers Trving New Routes, Officials Say. N.Y. TimES, June 1, 1998, at B6 (reporting that the prices that Chinese immigrants currently pay to be smuggled into the United States range from $\$ 40,000$ to $\$ 45,000)$.

72 The waiting period is generally five years. see 8 U.S.C. \$ 1427(a) (1994), but an immigrant who is married to a U.S. citizen may naturalize after only three years if they have been "living in marital union" during this period. Id. $\$ 1430$ (a). 
they could otherwise obtain may well stimulate skilled immigration at lower cost to natives than a formal negative tariff designed to be equally attractive. For example, for family-based immigrants, we might dispense with the requirement of employer sponsorship applied to employment-based immigrants. In fact, U.S. immigration laws require employer sponsorship only for employment-based visas: family-based immigration does not require a petition from a prospective employer. The prospect of family reunification may lead skilled aliens to come the United States who would not otherwise.

As an additional benefit for the immigrant family, we might also offer these family-based immigrants permanent residence and access to citizenship, which would imply nondiscriminatory taxes and access to public entitlements, even if we might otherwise admit aliens with similar skills only on nonimmigrant visas and impose a positive tariff on them. Before Congress enacted new restrictions on immigrant access to public entitlements in 1996, the United States generally provided such access to family-based immigrants even before naturalization: as legal permanent resident aliens, they enjoyed formal access to most of the public entitlements provided to citizens. While the new restrictions drastically curtail immigrant access to public benefits, U.S. law continues to provide permanent resident aliens greater access to public benefits than that enjoyed by nonimmigrant aliens. Furthermore, as permanent residents, family-based immigrants are eligible to naturalize as U.S. citizens, and once naturalized, enjoy the same fiscal policies applied to U.S. natives. This equal treatment, even for less skilled immigrants, may be in the economic interest of natives insofar as skilled aliens contemplating immigration to the United States take into account the benefits their relatives will enjoy as family-based immigrants.

In this sense, family-based immigration may act as an implicit negative tariff. Like an explicit negative tariff, family-based immigration may reduce the external benefits associated with each individual skilled immigrant, but as long as the family as a whole does not impose a net cost, family-based immigration may stimulate enough skilled immigration to be in the economic interest of natives. Furthermore, the presence of a sponsoring relative in the United States improves the likelihood that the sponsored relatives will integrate 
smoothly into the U.S. economy and will thus yield external benefits for natives rather than costs. Thus, an offer of family-based immigration may be an efficient means to improve our employment offer to skilled immigrants while maintaining a nondiscriminatory tax system.

We have already seen that it may be efficient to allow even the least skilled immigrant to bring a spouse and dependent children. The efficient policy may vary with the wealth of the immigrant, insofar as a wealthier immigrant may be willing to pay more for the immigration of a given relative. In this case, the economic value of a relative's immigration may be more likely to exceed the external costs that the relative would impose on natives. Given that skilled immigrants have higher levels of wealth than unskilled immigrants, their willingness to pay for the immigration of relatives may make it efficient to admit more distant relatives of skilled immigrants than of unskilled immigrants. If so, it may be optimal to allow skilled immigrants to sponsor a wider set of relatives than unskilled immigrants. In fact, under current U.S. law, immigrants may petition for the immigration of not only their spouses and children but ultimately also their parents, adult sons and daughters, and siblings. ${ }^{73}$ The United States does not grant temporary workers "permanent resident" status, however, and so they may not petition for the admission of the same classes of relatives (either as immigrants or nonimmigrants), but they may bring spouses and minor children with them into the United States as nonimmigrants. ${ }^{74}$

Although an immigrant may have access to some public benefits after admission to the United States (and full access after naturalization), any alien deemed "likely at any time to become a

73 Permanent resident aliens may sponsor their spouses, children (under the age of 21), unmarried sons, and unmarried daughters for immigrant visas subject to quotas. See 8 U.S.C. $\$ 1153(a)(2)(1994)$. Once an immigrant naturalizes as a U.S. citizen. then like other citizens, the immigrant may sponsor a spouse, children, and parents, who can obtain immigrant visas available for "immediate relatives" without quantitative limits. See id. \$1151(b)(2)(A)(i). All U.S. citizens may also sponsor their "unmarried sons or daughters," id. \$1153(a)(1), "married sons or married daughters," id. \$1153(a)(3), and "brothers or sisters," id. \$1153(a)(4), for immigrant visas, with each category subject to quotas.

74 See id. \$1101(a)(15)(H). 
public charge" may be excluded. ${ }^{75}$ In making this determination, consular officers consider the alien's age, health, education, skills, and assets. ${ }^{76}$ Based on such evidence, consular officers have broad powers to screen out immigrants expected to have a negative effect on the public treasury. This inadmissibility ground serves to ensure that family-based immigration as well as employment-based immigration is likely to have a net positive effect on the economic welfare of natives.

In fact, in the most careful and complete empirical analysis of the fiscal impact of immigration to date, the National Research Council found that even before Congress enacted new restrictions on immigrant access to public benefits in 1996, immigrants would have a net positive effect on the public treasury: that is, they and their descendants are likely to pay more in taxes than they will consume in public benefits. The Council estimates that the average immigrant will produce a net fiscal benefit of $\$ 80,000$ overall in net present value in 1996 dollars." This surplus is striking because the Council's calculation includes all immigrants, including refugees and unauthorized immigrants, ${ }^{78}$ who are not subject to the "public charge" inadmissibility ground and have thus tended to be less educated and poorer than employment-based and family-based immigrants. ${ }^{79}$

75 Id. \$ 1182(a)(4); see LEGOMSKY, supra note 50. at 316 ("Over the years, the public charge provision has become the single most common affirmative substantive basis for denials of immigrant visas and one of the most common for nonimmigrants ...." (footnotes omitted)).

${ }^{76}$ See 8 U.S.C. $\$ 1182($ a)(4)(B)(i) (Supp. II 1996).

77 See NRC, supra note 19. at 334 (Table 7.5).

78 See id. at 306 ("In principle, these surveys cover illegal immigrants as well as legal immigrants .... In our analysis we cannot distinguish between legal and illegal immigrants.").

79 See id. at 194 (noting that among legal immigrants, "refugees or asylees and their spouses have the lowest occupational earnings"); MICHAEL FIX \& JEFFrEY S. PASSEL, ImMigRation and ImmigRants: Setting the Record Straight 5, 31, 34. 37 (1994) (presenting evidence that unauthorized immigrants and refugees tend to have less education and lower incomes than other immigrants). Those seeking admission as refugees are not subject to the "public charge" inadmissibility ground. See 8 U.S.C. \$ 1157(c)(3) (1994). Furthermore. as Michael Fix and Jeffrey Passel note: "The only major immigrant population eligible to participate broadly in the nation's welfare state from date of entry is refugees." FIX \& PASSEL, supra, at 63. Their data indicate that refugees receive welfare at far higher rates than other immigrants. See id. at 63, 65 (Figure 21); see also id. at 58 ("When refugees are excluded. it becomes clear that immigrants of working age are considerably less likely than natives of working age to receive welfare."). 
Furthermore, the Council estimates that the 1996 welfare legislation would improve the total fiscal impact of the average immigrant by $\$ 8,000$ by excluding immigrants from various means-tested benefits. ${ }^{80}$ Thus, if the new welfare law has the effects predicted by its proponents, then the positive net fiscal impact of immigration will increase: the new restrictions would not only reduce the transfers paid to individual immigrants but also discourage the immigration of lowincome aliens.

To avoid the "public charge" inadmissibility ground, sponsoring relatives have often provided affidavits of support and evidence of their own incomes in order to gain the admission of the sponsored alien.' ${ }^{81}$ Thus, when the sponsored alien has had a low income, then the income of the sponsor would become relevant: this inadmissibility ground has in effect limited the right to sponsor low-income relatives to those petitioners with adequate levels of income. In short, the "public charge" provision has served to ensure not only that familybased immigrants impose little burden on the public sector but also that the formal right to petition for low-income family members is likely to prove valuable in effect only for immigrants with relatively high incomes. Consequently, the availability of these family-based visas serves as an incentive for skilled aliens in particular to choose to accept employment and residence in the United States.

In 1996, Congress imposed still more stringent requirements for family sponsorship that will further limit access to these visas and will tend to reserve them for sponsors with relatively high incomes. The Illegal Immigration Reform and Immigrant Responsibility Act of 1996 requires virtually all family-based immigrants to submit an affidavit of support. ${ }^{82}$ An affidavit of support must now be a contract enforceable against the sponsor not only by the sponsored alien but also by a federal, state, or local agency seeking reimbursement for benefits

80 See NRC, supra note 19, at 339.

81 See, e.g. Kohama, 17 I. \& N. Dec. 257 (1978).

82 The new law states that any alien seeking admission as a family-based immigrant, with only very narrow exceptions, is inadmissible unless the alien's sponsor executes an affidavit of support. See Illegal Immigration Reform and Immigrant Responsibility Act of 1996, Pub. L. No. 104-208. sec. $531(\mathrm{a}), \S 212(\mathrm{a})(4)(\mathrm{C}), 110$ Stat. 3009-546, 647 (codified at 8 U.S.C. $\$$ $1182(\mathrm{a})(4)(\mathrm{C})$ (Supp. II 1996)). 
provided to the sponsored alien under a means-tested entitlement program. ${ }^{83}$ The affidavit must bind the sponsor "to provide support to maintain the sponsored alien at an annual income that is not less than 125 percent of the Federal poverty line." ${ }^{84}$ The sponsor must demonstrate "the means to maintain" at least this level of income for "a family unit of a size equal to the number of members of the sponsor's household (including family and non-family dependents) plus the total number of other dependents and aliens sponsored by that sponsor. ${ }^{185}$

These requirements will not only improve still further the effect of family-based immigrants on public coffers but also deter or preclude those of modest means from sponsoring relatives for immigration. ${ }^{86}$ These requirements also ensure that the availability of family-based immigration visas will prove most valuable for the immigrants with the most wealth, because the number of relatives an immigrant can sponsor will be directly related to the immigrant's wealth. Furthermore, the legally binding obligations entailed by sponsorship will ensure that immigrants will sponsor only those relatives with

83 See 8 U.S. C. \$1 183a (Supp. II 1996). Furthermore. under welfare legislation enacted by Congress that same year, if the immigrant beneficiary of such an aftidavit later applies for "any Federal means-tested public benefits," then the immigrant's income and resources shall be "deemed" to include the income and resources of the sponsor. until the beneficiary either obtains U.S. citizenship or has worked for a sufficient period of time ("40 qualifying quarters"). Personal Responsibility and Work Opportunity Reconciliation Act. sec. 421. Pub. L. No. 104-193, 110 Stat. 2105, 2270 (codified at 8 U.S.C. \$ 1631 (Supp. 11 1996)). Thus, "deeming" will render otherwise eligible immigrants ineligible for public benefits.

848 U.S.C. $1183 \mathrm{a}(\mathrm{a})(1)(\mathrm{A})$ (Supp. 11 1996).

85 Id. \$ $1183 \mathrm{a}(\mathrm{f})(1)(\mathrm{E}),(6)(\mathrm{A})(\mathrm{iii})$. The law allows a sponsor who fails to meet this requirement to recruit another sponsor who can satisfy the requirement by accepting joint and several liability. Id. $\$ 1183 \mathrm{a}(\mathrm{f})(2),(5)$. This legal liability. however, is likely to deter all but close relatives from serving as sponsors. See Charles Wheeler. The New Affidavit of Support and Sponsorship Requirements, 74 INTERPRETER RelEASES 1581, 1591 (Oct. 20. 1997) ("[I]t is doubtful that many non-relatives would agree to a request to be a co-sponsor, given the potential liability that co-sponsors would be assuming.").

${ }^{86}$ Preliminary research sponsored by the Immigration and Naturalization Service found that $30 \%$ of those who sponsored relatives for immigration in 1994 had incomes below the new standard. See Celia W. Dugger, Immigrant Study Finds Many Below New Income Limit, N.Y. TIMES, Mar. 16, 1997, $\$ 1$, at 1 . Another study by the Urban Institute found that $40 \%$ of immigrant families and $26 \%$ of natives in the United States in 1993 had incomes below the new standard. See id. 
whom they have close ties. Immigrants will choose to sponsor only when they consider family reunification very valuable and only when the welfare of the sponsored relative matters a great deal to the sponsor. Thus, legal liability will restrict sponsorship of indigent immigrants to those cases in which family-based immigration will provide the most valuable incentive for the sponsor to immigrate.

Although restrictionists have proposed drastic cuts in family-based immigration, citing the national interest, ${ }^{87}$ these cuts may in fact reduce the economic welfare of natives by reducing the incentives for skilled immigration and by excluding valuable workers and taxpayers. Indeed, given the alternative of qualitative restrictions like the "public charge" inadmissibility ground as a device for regulating immigration, it is doubtful that quantitative restrictions on family-based immigration serve a useful purpose at all in the pursuit of national economic welfare. Liberalization or elimination of these quotas would probably serve the national economic interest better than cuts in these quotas.

Liberalized quotas would serve the interests of natives not only by increasing the immigration of valuable workers and taxpayers but also by allowing individual immigrants to enter sooner and thereby increasing the total economic contribution made by each immigrant. Quotas currently create backlogs of millions of family-based immigrants waiting for as long as ten years or more to enter the United States. ${ }^{88}$ The National Research Council found that immigrants arriving at earlier ages make a significantly larger net fiscal contribution overall because they will spend more of their working

87 The Jordan Commission. for example. recommended the complete elimination of most family-based admission categories, including not only siblings of U.S. citizens but also adult sons and daughters of U.S. citizens and of legal permanent residents. See JORDAN COMM'N. supra note 10, at 70-71. The Smith and Simpson bills sought to implement these recommendations. See H.R. 2202, supra note 15; S. 1394, supra note 15.

88 For example, as of January 1997, 1.5 million siblings of U.S. citizens were on the waiting list for immigrant visas, and those currently eligible to enter applied at least 10 years ago. See CIR, supra note 17, at 66. Sibling immigrants from oversubscribed countries had to wait even longer: those admitted from the Philippines, for example, applied nearly 20 years ago. See id. 
lives--and thus pay more taxes--in the United States. ${ }^{89}$ Perversely, the U.S. Commission on Immigration Reform has cited the backlogs for family-based immigrant visas as a reason to eliminate most categories of family-based immigration rather than as a reason to eliminate or liberalize the quotas. ${ }^{90}$ Liberalized quotas would reduce these backlogs, improve the fiscal impact of the average family-based immigrant, and would be more likely to promote the economic welfare of natives than the Commission's proposals. The Commission's restrictionist proposals seem particularly misguided, given the important changes in 1996 in the requirements for family sponsorship and in immigrant access to public benefits. Both sets of changes are likely to improve the fiscal effects of the average family-based immigrant. $^{9 !}$

Indeed, the new income test for family sponsorship sweeps so broadly that it applies to the sponsor regardless of the characteristics of the sponsored immigrant. Thus, the test seems over-broad and unduly rigid in that it will preclude the immigration of valuable workers and taxpayers simply because their sponsors have insufficient income. A test that would serve the interests of natives better would exempt sponsors from this test if the sponsored immigrant is likely to have a net positive effect on the public sector. For example, the National Research Council found that once we take account of the fiscal impact of an immigrant's descendants, the average immigrant with at least a high-school education will have a positive fiscal effect. ${ }^{92}$ Similarly, the Council also found that the average immigrant who arrives at age 40 or younger will have a positive fiscal effect. ${ }^{93} \mathrm{~A}$

${ }^{89}$ See NRC. supra note 19, at 328-35: see also CIR, supra note 17, at 66 (noting the "extended waiting periods" for immigrant visas for siblings of U.S. citizens, which "mean that most siblings enter well into their working lives, limiting the time during which they can make a contribution to the U.S. economy").

90 See CIR, supra note 17. at 66 (citing "the extraordinarily large waiting list for siblings of U.S. citizens, and to a lesser extent, adult children" and concluding that "[a]n end to extended [family] visa categories is justified").

91 By disqualifying many sponsors. the changes in sponsorship rules are likely both to reduce family-based visa backlogs and to create "a relatively wealthier mix" of family-based immigrants. Wheeler, supra note 85 , at 1591.

92 See NRC, supra note 19, at 334 (Table 7.5).

93 See id. at 335. 
liberalized rule that admitted young or educated immigrants regardless of the incomes of their sponsors would be more closely tailored to the national interest.

\section{InCome Distribution Among Natives}

The policies described above would maximize the total economic benefits for natives from immigration. While I have addressed how to maximize the total wealth of natives, I have not addressed the distribution of that wealth among natives. Immigration not only expands wealth, but also can have important distributive effects. Those natives who must compete with immigrants in the labor market may find that immigration reduces their real income.

Empirical studies, however, consistently find that immigration has only a weak effect on native wages. ${ }^{94}$ This result may not be surprising, given that natives and immigrants tend to work in different occupations and therefore tend not to compete in the same labor markets. ${ }^{95}$ Thus, immigration does have a more significant effect on the wages of earlier waves of immigrant workers, who are close substitutes for new immigrants. ${ }^{96}$

94 See id. at 223 (surveying the empirical studies and observing a "numerically weak relationship between native wages and immigration ... across all types of native workers. white and black. skilled and unskilled, male and female"); Borjas. Economics of Immigration. supra note 33, at 1697 (same); Friedberg \& Hunt, supra note 54, at 42 ("Despite the popular belief that immigrants have a large adverse impact on the wages and employment opportunities of the native-born population. the literature on this question does not provide much support for this conclusion.").

95 See NRC, supra note 19, at 218 (observing that immigrants are concentrated in occupations "at both the high and the low end of the educational distribution" and concluding that "the data suggest that the jobs of immigrant and native workers are different").

96 See id. at 223 ("The one group that appears to suffer significant negative effects from new immigrants are earlier waves of immigrants, according to many studies."). Borjas claims: "Ironically, even though the debate over immigration policy views the possibility that immigrants lower the wage of native workers as a harmful consequence of immigration. the economic benefits from immigration arise only when immigrants $d o$ lower the wage of native workers." Borjas. Economic Benefits from Immigration, supra note 23, at 10-11. This claim, however, refers only to the immigration surplus enjoyed by natives through the private sector in labor markets with native workers. If only immigrant workers take certain jobs, then 
On the other hand, even if present levels of immigration have little effect on native wages in the United States, a more liberal immigration policy could produce more significant effects. ${ }^{97}$ Thus, much of the support for immigration restriction is protectionist in nature: restrictionists often cite the need to protect U.S. workers from foreign competition. The requirement of labor certification, in particular, is designed to ensure that immigrants do not "take jobs away" from U.S. workers or drive down their wages.

If we wish to protect workers from these distributive effects, however, the appropriate response is not protectionism but redistribution. Optimal policies would liberalize immigration insofar as it increases the total wealth of natives. As long as immigration increases total wealth, then those who gain from immigration can compensate those who lose and still be better off. That is, those who gain by paying lower wages, or by buying products and services at lower cost, can afford to pay enough to compensate those who find their wages fall relative to prices. Redistributive policies can shift the costs of liberalized immigration to the beneficiaries of liberalization.

This redistribution would produce some costly distortions, but the deadweight loss of protectionism would be greater than the deadweight loss from redistributive taxes. That is, protectionism is less efficient than the tax system in producing a desirable distribution of income. ${ }^{98}$ For example, if the immigration of guestworkers reduces the wages of unskilled workers, then raising taxes on those with higher

natives can gain from immigration in these markets without driving down the wages of any native workers. See NRC, supra note 19. at 220 ("[T] he economic benefits of immigration that operate only through lower prices. without displacing or disadvantaging competitive domestic labor. add to the positive effects of immigration."). Furthermore, if immigrants generate a benet it for the public sector in the form of tax revenues, then natives can gain from immigration even if there is no effect on wages at all.

97 See NRC, supra note 19, at 220 (explaining that the wage effects of immigration are small in part because "the aggregate increase in the supply of labor caused by immigration is itself small").

98 We can always replace an economically inefficient rule with an efficient rule without making any income class worse off, provided that we make the appropriate adjustments in income taxes. See Louis Kaplow \& Steven Shavell, Why the Legal System is Less Efficient than the Income Tax in Redistributing Income, 23 J. LEGAL STUD. 667, 669 (1994); Steven. Shavell. A Note on Efficiency vs. Distributional Equity in Legal Rulemaking: Should Distributional Equity Matter Given Optimal Income Taxation', 71 AM. ECON. REV. PAPERS \& PROC. $41+(1981)$. 
incomes and reducing taxes on those with the lowest can leave all classes of natives better off than they would be in the absence of immigration. ${ }^{99}$ We can achieve this redistribution by expanding programs already in use under the existing U.S. income tax system: we could increase the earned income tax credit and liberalize its eligibility requirements, for example, to supplement the income of the working poor if liberalized immigration drives down their real wages. We can thereby reduce deadweight loss while still redistributing the same wealth that we currently redistribute through costly protectionism.

\section{IMPLICATIONS FOR REFORM}

Current immigration restrictions bear little resemblance to those that would maximize national economic welfare. The pursuit of this objective would probably entail levels of employment-based and family-based immigration higher than allowed by current laws. Given that the promotion of the interests of natives alone may seem offensive, however, because we do not truly believe that the welfare of immigrants should count for nothing, what normative implications can we draw from the preceding analysis for the reform of existing immigration laws? There are some liberalizing reforms that appear likely to improve matters compared to our current immigration laws, whether our measure of social welfare includes the interests of natives alone or includes the interests of immigrants as well. Liberalizing reforms that serve the interests of not only immigrants but also U.S. natives may stand the best chance of adoption, especially if we pursue such reforms in modest increments. Thus, I present these proposals not as ideal reforms but as the liberalizing reforms that seem most likely to prove politically feasible.

First, we should liberalize or eliminate our quotas on skilled immigrants and eliminate the "labor certification" requirements which impose protectionist restrictions on their immigration. We should also liberalize our quotas on family-based immigration, subject to the

99 See Barry R. Chiswick, Illegal Immigration and Immigration Control, J. ECON. PERSP., Summer 1988, at 101, 107. 
"public charge" inadmissibility ground, which provides an efficient incentive for skilled immigration while protecting public coffers. Furthermore, we should liberalize requirements for sponsorship of family-based immigrants so that young and educated immigrants are not excluded based solely on the income of their sponsors. Skilled immigration is in the interests of U.S. natives as well as of the immigrants.

Second, we should liberalize our existing guestworker programs so as to allow more unskilled aliens to work in the United States. We should eliminate "labor certification" requirements for guestworkers, which raise protectionist barriers to their employment. We should also liberalize our quotas on these admissions, our restrictions on the duration of their employment, and our limits on the length of their stay in the United States as workers. A liberalized guestworker program would be in the economic interest of natives as well as in the interest of the guestworkers. One question regarding national economic welfare arises with respect to the costs unskilled immigrants might impose through the public sector. To the extent this cost is a concern, the appropriate response would be fiscal: discriminatory fiscal policies can ensure that guestworkers impose no net external costs. Even with such discriminatory features, a liberalized guestworker program would be an improvement for the many aliens excluded by existing laws. Unskilled guestworkers also raise an issue with respect to the distribution of income among natives, but again the appropriate response is fiscal: to compensate unskilled native workers for any reduction in their real wages, Congress could combine immigration reforms with tax relief for the working poor, such as expansions in the earned income tax credit.

Why has the United States not moved toward such policies? Part of the problem may be the xenophobia and intolerance that have unfortunately always exerted a powerful influence on the formulation of immigration policies. Part of the explanation may be the same protectionist pressures generated by special interest groups that oppose liberalized trade in goods: those who fear foreign competition lobby for protectionist barriers. Unskilled native workers, for example, may oppose the immigration of guestworkers. To the extent Congress links a liberalized guestworker program with subsidies for the working 
poor, however, progressive tax reforms designed to compensate unskilled labor could help overcome opposition to liberalization.

The United States might also employ the same device used in the international trade context to overcome the protectionist opposition to liberalizing reforms: multilateral agreements in which each country agrees to reduce trade barriers in exchange for liberalization by others. The prospect of reciprocal liberalization by our trading partners mobilizes domestic producer interests in support of the agreement that can offset the domestic producer interests opposed to liberalization of our policies. Through such agreements, each country can gain not only by obtaining access to foreign markets but also by overcoming protectionism at home and opening its own market.

So far, the United States has applied a double standard to the liberalization of trade in services:

\begin{abstract}
Although at the level of general principle the United States espoused the idea that negotiations on services should have comprehensive scope, the US position on the definition of services themselves had the effect of focusing the negotiations on those sectors of most export interest to the United States and other developed countries (e.g. cross-border transactions in sectors such as telecommunications and financial services), while excluding liberalization of factor movements, especially labour, where developing countries might often have a comparative advantage (e.g. ship's crews, construction gangs, etc.). ${ }^{100}$
\end{abstract}

In the initial negotiations over the GATS, the United States failed in its efforts to obtain a "hard" agreement along GATT lines, with generally binding obligations, including a "national treatment" obligation, which would prohibit discrimination against foreign suppliers of services. ${ }^{101}$

To promote more comprehensive liberalization in the future, the United States could agree to place its own immigration policies regarding temporary workers on the negotiating table under the

100 TREBILCOCK \& HOWSE, supra note 2, at 226.

101 See Hoekman, supra note 2, at 925. 
auspices of the GATS. ${ }^{102}$ In exchange for commitments by the United States regarding temporary workers, labor-abundant developing countries may be more inclined to agree to liberalize their markets for services in which the United States has a comparative advantage. ${ }^{103}$ The United States would gain not only by reforming its own immigration laws, but also by obtaining commitments by developing countries that they have been reluctant to make thus far (such as a "national treatment" obligation for services).

Negotiations would provide a justification for our failure to adopt more liberal immigration laws. Whereas in an ideal world we might adopt more efficient laws, we currently live in a highly nonideal world in which other govemments discriminate against our nationals (in their goods markets, service markets, labor markets, or capital markets). Given this reality, we may use costly policies as bargaining chips, offering to reform our protectionist policies in exchange for liberalizing reforms by other governments that discriminate against our nationals. Reforms implemented through a multilateral agreement

102 See GATS Annex, supra note 9. para. 3, 33 I.L.M. at 1188 ("Members may negotiate specific commitments applying to the movement of all categories of natural persons supplying services under the Agreement."); Sauve, supra note 2, at 134 ("The Annex ... establishes that Members may negotiate specific commitments applying to the temporary entry of all categories of natural persons").

The development of this Annex was--and remains--of particular interest to developing countries, given the comparative advantage many of them enjoy' in labour-intensive services (e.g. construction services, software development, engineering design). Recognition of the fact that most developed countries had not included categories of greatest interest to developing-country exporters led to the adoption of a Ministerial Decision calling for negotiations to continue beyond the conclusion of the Uruguay Round and aimed at achieving higher levels of commitments by GATS Members.

Sauve. supra note 2, at 135.

103 The government of a country sending workers to the United States would perceive a benefit from liberalized guestworker policies as long as it remains concemed about the welfare of these workers. Furthermore, even if that government no longer regarded such workers as its constituents, the tendency of migrant workers to send remittances back home to help support friends and family left behind would represent an important benefit for the country of emigration. For example, a recent study estimated that Mexican migrants in the United States send between $\$ 2.5$ billion and $\$ 3.9$ billion per year back home to Mexico, the equivalent of about half the direct foreign investment in Mexico. See Sam Dillon. U.S.Mexico Study Sees Exaggeration of Migration Data. N.Y. Times, Aug. 31, 1997. \$ 1. at 1, 6. 
would allow each participant to increase its national economic welfare while improving global economic welfare. 